\title{
Nieznane źródło do dziejów parafii w Małogoszczu (inwentarz kościelny z 1786 roku)
}

Abstract

\section{Unknown source for the history of the Małogoszcz parish (the church inventory of 1786)}

$\mathrm{T}$ he parish under the invocation of the Assumption of the Blessed Virgin Mary in Małogoszcz (the Świetokrzyskie province) is one of the oldest in the Kielce diocese. It was erected in the first half of the $12^{\text {th }} \mathrm{c}$., and in 1342 was lavishly endowed by the King Casimir the Great. From the beginning of the $14^{\text {th }} \mathrm{c}$. it was part of the Kurzelow archdeaconry of the Gniezno archdiocese, and three centuries later it became the seat of the deanery. The first, wooden parish church was burnt down by the Tatars in 1259. Little is known about the second one. The present, stone temple was built at the end of the $16^{\text {th }} \mathrm{c}$. in the Renaissance style by the priest Jakub Bieda Chrostkowic. This priest founded two other churches in Małogoszcz: branch church dedicated St. Stanislaus on the Babinek hill (now a cemetery one, being in a ruin) and the hospital church of St. Cross (not preserved).

The basis for the edition of the source (placed at the end of the article) is the inventory of the parsonage of 1786 from the collections of the Diocesan Archives in Kielce. This manuscript has not been previously published or exploited by historians. It describes a presbytery, a manor house, the farm buildings, a brewery, two inns, and also lists livestock and dead stock. This source significantly enriches our knowledge about the Małogoszcz parish in Old Poland period.

Keywords: Małogoszcz parish, church inventory, source edition, 1786 
StreszcZenie

D arafia pw. Wniebowzięcia Najświętszej Marii Panny w Małogoszczu (woj. świętokrzyskie) należy do najstarszych na terenie diecezji kieleckiej. Została erygowana w pierwszej połowie XII stulecia, a w 1342 r. hojnie uposażona przez Kazimierza Wielkiego. Od poczatku XIV w. wchodziła w skład archidiakonatu kurzelowskiego archidiecezji gnieźnieńskiej, trzy stulecia później stała się zaś siedzibą dekanatu. Pierwszy, drewniany kościół parafialny został spalony przez Tatarów w 1259 r. O drugim niewiele wiadomo. Obecna, murowana świątynia została wzniesiona pod koniec XVI w. w stylu renesansowym przez ks. Jakuba Biedę Chrostkowica. $Z$ fundacji tego duchownego powstały w Małogoszczu także dwa inne kościoły: filialny pw. św. Stanisława na wzgórzu Babinek (obecnie cmentarny, w ruinie) i szpitalny pw. św. Krzyża (niezachowany).

Podstawę edycji źródła (zamieszczonego na końcu artykułu) stanowi inwentarz plebanii z 1786 r., przechowywany w zbiorach Archiwum Diecezjalnego w Kielcach. Rękopis ten nie był wcześniej publikowany ani wyzyskiwany przez historyków. Opisano w nim plebanię, folwark, zabudowania gospodarcze, browar, dwie karczmy, wyszczególniono żywy i martwy inwentarz. Źródło to w istotny sposób wzbogaca naszą wiedzę o parafii małogoskiej w czasach staropolskich.

Słowa kluczowe: parafia Małogoszcz, inwentarz kościelny, edycja źródłowa, 1786 rok

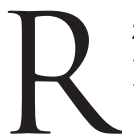

zymskokatolicka parafia pw. Wniebowzięcia Najświętszej Marii Panny w Małogoszczu należy do najstarszych i najbardziej znaczacych na terenie diecezji kieleckiej. Odznacza się ponadto burzliwa, bogato udokumentowaną źródłowo historia. Małogoszcz, jako leżący na trasie z Łęczycy do Sandomierza i Krakowa, a potem $z$ Warszawy do Krakowa, był często odwiedzany przez królów polskich (gościli tu m.in. Kazimierz Wielki, Władysław Jagiełło, Stefan Batory czy Stanisław August Poniatowski), jak również inne znamienitości, wśród których nie zabrakło kobiet (w 1140 r. przebywała tu ks. Salomea, wdowa po Bolesławie Krzywoustym, a w 1273 r. bł. Kunegunda, księżna krakowska i sandomierska). W 1655 r. maszerował przez miasto na czele swych wojsk Karol X Gustaw, a w 1702 r. inny szwedzki monarcha - Karol XII kwaterował na plebanii. Małogoszcz był także miejscem zaciętych walk w czasie insurekcji $1863 \mathrm{r} .{ }^{1} \mathrm{Na}$ cmentarzu parafialnym znajduje się wspólna mogiła poległych w boju powstańców (175 osób) oraz grób ich dowódcy - kpt. Stanisława Jaszowskiego. Spoczęli tu też dwaj oficerowie $z$ czasów insurekcji kościuszkowskiej:

1 Por. ostatnio: C. Jastrzębski, Bitwa pod Małogoszczem 1863, Małogoszcz 2013. 
gen. Jan Grochowski i gen. Józef Wodzicki. Przykłady na historyczność i wagę tej parafii można by mnożyć ${ }^{2}$. Mimo niebagatelnej roli, jaką odegrała ona zarówno w życiu społeczności lokalnej, jak i w dziejach narodu polskiego, parafia małogoska nie doczekała się dotąd własnej monografii. Tym bardziej więc zachodzi potrzeba publikowania wszelkiego rodzaju źródeł (zwłaszcza $z$ okresu staropolskiego, dla którego przepadło gros dokumentów kościelnych $z$ terenu dawnego archidiakonatu kurzelowskiego), przybliżajacych jej bogatą i niełatwa momentami historię ${ }^{3}$.

Erygowana w pierwszej połowie XII w., parafia małogoska została hojnie uposażona przez króla Kazimierza Wielkiego w 1342 r. Monarcha za zasługi dla kraju darował miejscowemu plebanowi Janowi (i jego następcom) zachodnią część miasta, rozległy kompleks gruntów od cmentarza do rzeki Pierzchnicy (vel Pierzchnianki) oraz wieś Popowice. Nadanie uzupełnione zostało cłem z Małogoszcza, Kurzelowa i Chęcin, a także dwoma świątnikami $z$ tutejszych mieszczan do obsługi kościoła. Od tego czasu beneficjum małogoskie zaliczane było do bardziej intratnych, a ponieważ było kolacji monarszej, przeważnie otrzymywali je wysocy dygnitarze duchowni. O zamożności parafii świadczy również fakt, że obejmowała ona swym zasięgiem stosunkowo rozległy obszar ${ }^{4}$,

${ }^{2}$ Więcej w tym temacie por. J. Wi śn niew s ki, Historyczny opis kościołów, miast, zabytków i pamiątek w Jędrzejowskiem, Marjówka 1930 (reprint: Kielce 2000), s. 105 i n.

${ }^{3}$ Przedmiotem edycji źródłowych były dotąd: sumariusz parafii małogoskiej w 1792 r., protokół wizytacji dziekańskiej z 1830 r. oraz inwentarz fundi instructi z 1856 r. Por. M. Karkocha, Uposażenie parafii Małogoszcz w świetle sumariusza z 1792 r., „Przegląd Nauk Historycznych” 2016, R. XV, nr 1, s. 249-276; eadem, Opis wizyty dziekańskiej kościoła parafialnego w Małogoszczu $z$ roku 1830, „Przegląd Nauk Historycznych” 2016, R. XV, nr 2, s. 261-283, https:// doi.org/10.18778/1644-857X.15.02.09; e a d e m, Wystrój i wyposażenie kościoła parafialnego $w$ Małogoszczu $w$ świetle inwentarza z 1856 roku, „Przegląd Nauk Historycznych” 2017, R. XVI, nr 1, s. 325-362, https://doi.org/10.18778/1644-857X.16.01.10; eadem, Opis probostwa w Małogoszczu z 1856 roku, „Przegląd Nauk Historycznych" 2018, R. XVII, nr 1, s. 143-170, https://doi.org/ 10.18778/1644-857X.17.01.07; eadem, Prebenda św. Anny w Małogoszczu $w$ połowie XIX stulecia, „Przegląd Nauk Historycznych” 2018, R. XVII, nr 2, s. 269-284, https://doi.org/10.18778/1644-857X.17.02.11 (= St. Anne's prebend in Małogoszcz in the mid-nineteenth century, "Przegląd Nauk Historycznych” 2018, R. XVII, nr 3, s. 271-286, https://doi.org/10.18778/1644-857X.17.03.11).

${ }_{4}$ Początkowo miasto Małogoszcz i osiem wsi (Bolmin, Cieśle, Gnieździska, Leśnica, Popowice, Skorków, Zajączków, Ruda Zajączkowska), od XVI w. także dwór Lasochów. W 1574 r. w Bolminie erygowana została odrębna parafia. Pozostałe miejscowości należały do małogoskiego okręgu parafialnego jeszcze w XIX w. 
a w XVIII w. jej rządcy mieli swoich koadiutorów, tj. pomocników $z$ prawem następstwa po zawakowaniu beneficjum ${ }^{5}$.

Murowany kościół parafialny, służący wiernym do dziś, został wzniesiony w latach 1591-1595 r. z fundacji ks. Jakuba Biedy Chrostkowica (Chrostkowicza, Chrostka) (1560-1630), miejscowego mansjonarza, późniejszego proboszcza i dziekana małogoskiego ${ }^{6}$. Konsekrował go w 1595 r. biskup chełmiński i wieczysty administrator diecezji pomezańskiej, a uprzednio pleban w Małogoszczu - ks. Piotr Tylicki (1543-1616) ${ }^{7}$. Jest to budowla orientowana, jednonawowa, $z$ wyodrębnionym prezbiterium zamkniętym trójbocznie. Od północy do prezbiterium przylega zakrystia i niewielki skarbczyk, a do nawy kaplica pw. Matki Boskiej Różańcowej oraz pięcioboczna przybudówka $z$ kruchtą w przyziemiu i składzikiem na piętrze. Po przeciwnej stronie znajduje się kaplica dedykowana św. Annie, a od zachodu masywna czworoboczna wieża, wzniesiona w 1624 r. W drugiej połowie XVIII stulecia świątynia, niemająca

Por. M. Karkocha, Opis probostwa w Małogoszczu..., s. 147 i 155-156 (tabela); e ad e m, Opis wizyty dziekańskiej..., s. 267.

5 J. Wiśniewski, op. cit., s. 116-117, 262; E. Kosik, Parafia małogoska, [w:] W kasztelańskim Małogoszczu. Monografia historyczno-gospodarcza Małogoszcza i okolicy, red. E. Kosik, Kielce 1994, s. 60-61; C. Had a mik, D. Kalina, E. Traczyński, Miasto i gmina Małogoszcz, Kielce 2006 (seria: Dzieje i zabytki małych ojczyzn, red. R. Mirowski), s. 118-119; M. Rawita-Witanowski, Dawny powiat chęcinski, z ilustracjami prof. J. Olszewskiego, oprac. D. Kalina, Kielce 2001, s. 104, 108.

${ }^{6}$ Poszczególne etapy budowy i wyposażania świątyni poświadczają liczne tablice inskrypcyjne. Por. Corpus inscriptionu Poliniae, t. I (Województwo kieleckie), red. J. Szymański, z. 2 (Jędrzejów i region jędrzejowski), wydała, wstępem i komentarzem opatrzyła B. Trelińska, Kielce 1978, s. 100-108 (nr 97-108). Na temat ks. Chrostkowica por. J. Wiśniewski, op. cit., s. 214-231; M. Rawita-Witanowski, op. cit., s. 109-119; E. Kosik, Chrostowice z Małogoszcza, „Nasza Przeszłość" 1973, R. XL, s. 176-181; ide m, M. Paulewicz, Budowniczy Małogoszcza Jakub Bieda Chrostkowicz, [w:] W kasztelańskim Małogoszczu..., s. 67-70.

7 Wzmiankuje o tym np. inwentarz kościła i parafii z 1856 r. (por. M. Karkocha, Opis probostwa w Małogoszczu..., s. 150-151), a potwierdza tablica inskrypcyjna umieszczona w prezbiterium na ścianie północnej (por. Corpus inscriptionum..., s. 102, nr 99; M. Karkocha, Epigrafika w Małogoszczu XVI-XVIII w., „Acta Universitatis Lodziensis. Folia Historica” 2015, nr 95, s. 25-26 oraz il. 2 na s. 30). Biogram P. Tylickiego: L. Łętowski, Katalog biskupów, prałatów i kanoników krakowskich, t. II (Biskupi krakowscy), Kraków 1852, s. 162-169; B. Kum or, Dzieje diecezji krakowskiej do roku 1795, t. I, Kraków 1998, s. 520521; S. Achremczyk, R. Marchwiński, J. Przeracki, Poczet biskupów warmińskich, Olsztyn 1994, s. 125-127; P. Nitecki, Biskupi Kościoła w Polsce w latach 965-1999, Warszawa 2000, s. 458. 
wówczas zachodniej kruchty (dobudowana w 1894 r.) ${ }^{8}$, znajdowała się w złym stanie technicznym. W dokumencie z 1779 r. czytamy: „A że i reperacja kośc. zachodzi przez upadająca dachówkę i pogniłe krokwy, zaczym ta od dyspozycji JWX. kanclerza ma zawisnać, o której jednak tenże JWX. kanclerz zaradzić jak najprędzej obliguje się, aby w ruinę nie szedł kościół. Interea dla uniknięcia jesiennych niepogód, aby zacieki nie rujnowały sklepień i murów do reszty (!)" 9 . Remont generalny światyni parafialnej został przeprowadzony dopiero w latach 1796-1800. Wymieniono wówczas zniszczoną więźbę dachową i położono nową dachówkę, dokonano też reperacji sklepień. Dzięki temu nie podzieliła ona losu kościoła szpitalnego pw. św. Krzyża, który popadł w ruinę i został rozebrany w XIX stuleciu ${ }^{10}$.

Pod względem kościelnym parafia małogoska przynależała do archidiecezji gnieźnieńskiej, a po utworzenia archidiakonatu kurzelowskiego na początku XIV w. znalazła się w jego granicach. Około 1604 r. Małogoszcz stał się siedzibą dekanatu liczacego 15 parafii (Bolmin, Chełmce, Chęciny, Cierno, Grzymałków, Kozłów, Krasocin, Łopuszno, Małogoszcz, Mnin, Mniów, Rembieszyce, Strawczyn, Węgleszyn i Złotniki). Do połowy XVIII stulecia dziekanami byli na ogół proboszczowie małogoscy, natomiast w późniejszym czasie funkcję tę sprawowali przeważnie kanonicy kurzelowscy ${ }^{11}$.

\section{Podstawa wydania}

Przedmiotem edycji źródłowej jest najstarszy znany mi inwentarz parafii małogoskiej (i prawdopodobnie najstarszy zachowany), spisany 20 czerwca 1786 r. Dokument nie był wcześniej publikowany ani wyzyskiwany przez historyków. Przechowywany jest w zbiorach Archiwum Diecezjalnego w Kielcach, w poszycie zatytułowanym Małogoszcz. Dokumenty różne z XIX wieku (luzem, nieuporzadkowane), oznaczonym sygnatura IIPM-I/6. Jest to rękopis w języku polskim, liczący sześć kart formatu zbliżonego do

8 J. Wiśniewski, op. cit., s. 118-119; E. Kosik, Parafia małogoska..., s. 63; C. Hadamik, D. Kalina, E. Traczyński, op. cit., s. 176-177; Katalog zabytków sztuki w Polsce, t. III (Województwo kieleckie), red. J.Z. Łoziński, B. Wolff, z. 3 (Powiat jędrzejowski), oprac. T. Przypkowski, Warszawa 1957, s. 18.

9 Cyt. za: J. Wiśniews ki, op. cit., s. 262.

10 Ibidem, s. 263-264; E. Ko sik, Parafia małogoska..., s. 66.

11 J. Wiśniewski, op. cit., s. 162-163; E. Kosik, Parafia małogoska..., s. 59, 63-65. 
A4, obustronnie zapisanych i pierwotnie niepaginowanych (obecnie k. 33-38). $Z$ dopisku na ostatniej karcie można wnioskować, że inwentarz został sporządzony $\mathrm{w}$ związku $\mathrm{z}$ przejęciem probostwa i wsi Popowice w maju 1787 r. w trzyletnią dzierżawę przez Kajetana Zakrzewskiego, cześnika bracławskiego, dziedzica Lipnika i Lipniczki w dawnym powiecie sandomierskim ${ }^{12}$. Dokument podpisali i uwierzytelnili swoimi pieczęciami ks. Ignacy Józef Malczewski h. Tarnawa (1749-1809) ${ }^{13}$, doktor obojga praw i miejscowy proboszcz, oraz wspomniany Zakrzewski. Należy dodać, że lektura omawianego źródła nie należała do łatwych zarówno $z$ powodu cech pisma (kursywna forma, z licznymi ozdobnikami), jak i złego stanu zachowania samego dokumentu (szereg ubytków w tekście spowodowanych poplamieniami, wyblakłym atramentem czy niefachowa oprawą kart) i gdyby nie pomoc osób trzecich, zaniechałabym próby jego odczytu ${ }^{14}$.

\section{Metoda wydawnicza}

Edycja inwentarza został przygotowana na podstawie instrukcji wydawniczej dla źródeł nowożytnych, opracowanej przez Kazimierza Lepszego ${ }^{15}, z$ pewnymi jednak modyfikacjami. Stosownie do dominujacej ostatnio $\mathrm{w}$ tego typu wydawnictwach tendencji nie dokonano pełnej modernizacji pisowni wyrazów staropolskich, zachowujac ich cechy językowe. Bez zmian pozostawiono zatem końcówki: -emi, -yma, jak również charakterystyczne staropolskie oboczności językowe: „kumin” - komin, „probocztwo” - probostwo, „wszedszy” - wszedłszy, „żena” - żona itp. Uwspółcześniono pisownię wielkich i małych liter oraz poprawiono interpunkcję. Uzupełniono tekst o znaki diakrytyczne jak: „ć”, „ńn”, „ś, „ź, „ź", niekiedy „ę". Samogłoski „i”, „y” oraz spółgłoskę „j” oddano zgodnie z dzisiejszą praktyką (np. „iest”, „lewey”, „staynia” zamieniono na

${ }^{12}$ Potwierdza to ks. Jan Wiśn niews ki (op. cit., s. 264), podając, że Zakrzewski dzierżawił miejscowe beneficjum za 4500 zł rocznie. W roku 1790 dzierżawa została przedłużona na kolejne trzy lata za $4000 \mathrm{zł}$ rocznie.

13 Informacje biograficzne o tym kapłanie: ibidem, s. 262-266. Dodajmy na marginesie, że zachował się inwentarz fundi instructi z 1810 r., spisany po śmierci ks. Malczewskiego (Archiwum Diecezjalne w Kielcach, Małogoszcz. Akta dokumentów kościoła parafialnego w Małogoszczu od 1709 r., sygn. IIPM-I/2, k. 53-73v).

${ }_{14}$ Serdecznie dziękuję mojej siostrze, mgr Agnieszce Kraus i mamie, Mariannie Karkosze za nieocenioną wręcz pomoc w odczytaniu publikowanego rękopisu.

${ }^{15}$ Instrukcja wydawnicza dla źródeł historycznych od XVI do połowy XIX wieku, red. K. Lepszy, Wrocław 1953. 
„jest”, „lewej”, „stajnia”). Podwojone głoski „ss” zastąpiono pojedynczymi (m.in. w wyrazach „lassy”, „possessor”, „wssiew”). Znak „ó" zastosowano według obecnych reguł pisowni, a literę „x" transkrybowano przez „ks” (np. w zapożyczonym $z$ języka łacińskiego słowie „excypować”). W edycji pominięto wyraz powtarzający się $z$ poprzedniej strony w podstawie źródłowej oraz zmodernizowano i ujednolicono zapis jednostek monetarnych. Wyrazy, które odbiegają od współczesnej pisowni, a nie zostały poprawione przez wydawcę, opatrzono skróconym sic w nawiasie kwadratowym [s] dla upewnienia czytelnika o zgodności tekstu wydanego $z$ podstawa. W takich samych nawiasach umieszczono paginację rękopisu, rozwiązano skróty i daty, a także dopisano opuszczone przez pisarza litery. W przypisach tekstowych zamieszczono uwagi odnoszace się do postaci zewnętrznej i brzmienia podstawy źródłowej. W przypisach rzeczowych objaśniono wzmiankowane osoby i miejscowości oraz trudniejsze terminy. Zachowano podkreślenia i układ tekstu jak w oryginale.

\section{TEKST ŹRÓDEOWY}

\section{Inwentarz probocztwa małogoskiego na gruncie zweryfikowany i spisany dnia 20 miesiąca czerwca R[ok]u Pańskiego 1786}

Oryg.: Archiwum Diecezjalne w Kielcach, Małogoszcz. Dokumenty różne z XIX wieku (luzem, nieuporządkowane), sygn. IIPM-I/6, k. 33-38.

[k. 33] Z przyjścia [?] od ulicy miejskiej sa wrota tarciczne nowe w okapie nowym, $z$ furtka o trzech wschodkach tarciczna nowa, na zawiasach, hakach, $z$ wrzeciądzem i skoblami żelaznemi, alias z klamką żelazna, wrotami na kunach żelaznych, $z$ wrzeciądzem i $z$ skoblami takimież $[s]$. Nad tą bramą i nad furtka nowo wystawiona jest daszek gontami pobity $z$ dwiema stybrami drewnianemi.

Stajnia przy tej bramie murowana pod gontami, $z$ żłobami, $z$ drabinami i z podłoga, miejscami reparacji potrzebuje, bez powały. W tej stajni jest komórka $z$ drzwiczkami na zawiasach i hakach, 
$z$ wrzeciądzem i z skoblami żelaznemi, do tej stajni sa drzwi tarciczne na zawiasach i hakach żelaznych, $z$ wrzeciądzem i skoblami żelaznemi.

\section{Chlewy przed browarem}

Idac do browaru, po prawej stronie tego chlew $z$ drzewa postawiony w słupy, na przyciesiach ${ }^{16}$ sosnowych, partem gontami pobity, partem snopkami poszyty, do którego drzwi dwoje na biegunach drewnianych, $z$ wrzeciądzami i skoblami żelaznemi. W tym zabudowaniu jest wołownia na bydło kamie[nna] $z$ żłobem, $z$ drobina na podłodze. Item ${ }^{17}$ mostków dwa przed tym chlewem $z$ dylów dane, dobre. Od browaru po lewej stronie ciagnie się parkan w słupach z dylów od ulicy miejskiej, otaczający dziedziniec, czyli plac jurysdykcji proboszczowskieja.

Między tym parkanem jest karmnik duży pod gontami $z$ dylów w słupy, na palikach postawiony. Oraz i chlew dla trzody przeforsztowany ${ }^{18}, z$ korytami, $z$ wózkami [?], $z$ podłogami, bez powały. Drzwi dwoje na biegunach drewnianych, w jednych wrzeciądz $z$ dwoma skoblami żelaznemi; do tego karmnika jest mostek dobry $z$ dylów dany.

\section{Browar}

Z drzewa sosnowego w kostkę pod topór obrabianego, w węgły postawiony, gontami pobity, $z$ kominem wielkiem od fundamentów murowany, w górze na stagach wałkami $z$ glina pleciony, na dach wywiedziony, $z$ kapa $z$ cegły wymurowaną.

Wchodzac do browaru, sa drzwi tarciczne na zawiasach, hakach żelaznych, $z$ wrzeciądzem, $z$ skoblami i $z$ klamka takiemiż do sieni. $Z$ sieni do gorzelni sa drzwi tarciczne na zawiasach, hakach żelaznych, $z$ klamka takąz. W tej gorzelni jest okien trzy w ramach, w których brakuje szyb pięciu. Posadzka do słodów ruszczania $z$ cegły, reparacji miejscami potrzebuje. Ry[k. 33v]n[n]a od rumice [?] w ziemi $z$ wiekiem dobra, druga ryn[n]a od kazkiej zalewnej pod przycieś dana dobra.

\footnotetext{
a Następuje fragment tekstu wymazany ręką autora.

16 Przycieś - podwalina ściany drewnianej.

17 Item (łac.) - wyszczególnienie, punkt.

18 Przeforsztowany - przepierzony, przegrodzony.
} 
W tej gorzelni jest izdebka dla pisarza $z$ kominkiem, nalepa $z$ piecem otynkowanym, wszystko $z$ kamienia murowane. Ta izdebka $z$ powałą bez podłogi, do której drzwi na zawiasach i hakach, $z$ wrzeciądzem i skoblami żelaznemi. Okno jedno dobre $z$ okiennica $z$ izde[b]kiej zasuwana. Przez [b] idac do szuszarni, sa drzwi na zawiasach, hakach $z$ haczykiem, skoblami i z klamka żelaznemi. $\mathrm{W}$ tej szuszarni jest piec do suszenia słodów $z$ kamienia murowany, cegła sklepiony, $z$ lasami ${ }^{19}$. Item skrzynia, czyli sąsiek wielki na surowce $z$ przegroda, u którego drzwiczki bez zawias[ów], $z$ wrzeciądzem i hakami, skoblami żelaznemi. Studnia przy browarze $z$ wiadrem dobra.

\section{Statki browarne}

Kocioł piwny żelazny w kotlinie jeden, garniec nowy wielki miedziany jeden, z pokrzywa i $z$ rurami miedzianemi nowemi, w kotlinie $\mathrm{w}$ murowanej $z$ kamienia. Rumica dębowa, na której obręczy żelaznych cztery, jedna. W browarku kadzic piwnych jedna duża, dwie pomniejszych № $\underline{3}$, pod któremi toków dwa na brzęczkę i na piwo. Okno w tym browarku, szyby w drewno oprawne jedno, góra przysworzenia potrzebuje. Item w gorzalni jest kadka nowa sosnowa do zalewania zboża na słody jedna, miarka do piwa w garncy pięćdziesiąt jedna. Ko[s]z do chmielu jeden, lej drewniany jeden, nalewek dwie, kotlina druga murowana próżna. Blacha do czeluści $^{20}$ żelazna jedna, beczek piwnych cztyrynaście, lagrówek ${ }^{21}$ beczek dwie, konew dębowa nowa o dwu uchach, w której gar[n]cy dziewiętnaście i półspustowa, konewek o jednym uchu dwie, skrobaczka do chędożenia gar[n]ca żelazna jedna, siekiera do gorzelni dobra jedna, klin żelazny do kloców łupania jeden, zaciernic ${ }^{22}$ $\underline{6} z$ wałami, przycierów $\underline{2}$ dobrych.

b Słowo nieczytelne.

c W źródle: „kazdzi”.

19 Lasy (dary) - krata $z$ drutu lub prętów drewnianych, dziurkowana blacha do suszenia słodu. Por. M. Dominikiewicz, Wyrób piwa, wyd. 2 na nowo oprac. i powiększone, Łódź-Katowice 1923, s. 48-49; K. Ła cny, M. J a n czar-S muga, Postęp techniczny $i$ technologiczny $w$ produkcji słodu, „Nauki Inżynierskie i Technologiczne" 2013, nr 4(11), s. 81.

${ }^{20}$ Czeluść - otwór w piecu służący do załadunku opału.

${ }^{21}$ Czyli odleżanego w lodowni, wystałego piwa.

22 Zaciernica - naczynie, w którym dokonuje się zacierania, kadź zacierowa. 


\section{$\underline{\text { Probocztwo }}$}

Rezydencja dosyć wspaniała, od fundamentów z kamienia murowana, gontami całe probocztwo pobite. Pod tymże probocztwem jest piwnic trzy, czwarte schowanie dobre. Te piwnice murowane i sklepione $z$ kamienia na wapnie, $z$ trzema kratami krzyżowemi żelaznemi w oknach. Intra ${ }^{23}$ kuminów murowanych na dach wyprowadzonych cztery. $Z$ podwórca do sieni dobrej sa drzwi nowe futrowane, na zawiasach i hakach fundamentalnych żelaznych, $z$ klamką i zasuwa takiemiż. W tej sieni jest okien dwoje dobrych. W tej sieni jest powała dobra, podłoga kamienna, miejscami poprawienia potrzebuje. Idąc przez sień, na lewej ręce jest schowanie dobre podobne piwnicy, do którego sa drzwi tarciczne sparowane na zawiasach, hakach, $z$ zamkiem, kluczem, wrzeciądzem i z skoblami dwiema żelaznemi, $z$ powałą dobra, bez podłogi. Okno jedno, w którym kwater nie masz, tylko krata drewniana. Legarów dwa. Notandum ${ }^{24}$ do trzech piwnic jest drzwi troje tarcicznych szaparowanych dobrych stolarska robota, na zawiasach i hakach gruntowych [?] żelaznych, $z$ wrzeciądzami i skoblami takiemiż do zamykania.

$\mathrm{Na}$ prawej stronie, idąc ku schodom, jest izdebka, do której [k. 34] sa drzwi tarciczne stolarska robota na zawiasach, hakach żelaznych, $z$ wrzeciądzem, skoblami, $z$ klamka żelaznemi oraz ab intra $^{25} z$ haczykami i $z$ dwiema skoblikami do zakładania. W tej izbie okien dwoje dobrych, szyby $w$ drewnie, $z$ powała i $z$ podłogą. Piec pół ceglany, pół z kafli zielonych $z$ pieczykiem chlebowym ceglanym, kominek $z$ cegły murowany kapiasty ${ }^{26}$.

$Z$ tej izdebki do szpiżarki sa drzwi tarciczne stolarska robota, na zawiasach, hakach, $z$ wrzeciązem i skoblami żelaznemi. Okno jedno dobre, szyby w drewno oprawne, $z$ podłoga, $z$ powała tarciczną nowa.

Idąc przez sień, jest schodów dwoje $z$ poręczami do góry. Wszedszy na tę górę, jest sień wielka na podłodze, z powałą dobrą tarciczna. W tej sieni okien dwoje w szybach taflowych, na zawiasach i hakach żelaznych, $z$ werblami ${ }^{27}$ takiemiż do zawierania kwater.

${ }^{23}$ Intra (łac.) - wewnattrz, w środku.

${ }^{24}$ Notandum (łac.) - notując.

25 Ab intra (łac.) - od wewnątrz.

${ }^{26}$ Kominek kapiasty $-\mathrm{z}$ wielką kapa (okapem), budowany w narożniku pomieszczenia.

${ }^{27}$ Werbel - haczyk żelazny. 
Z sieni na cmentarz sa drzwi tarciczne szparowane, na zawiasach i hakach żelaznych, $z$ zamkiem bez klucza i antaby, tylko rygel ab intra do zasuwania żelazny. Nad temi drzwiami do cmentarza jest okno dobre w ramach, szyby w ołów oprawne.

Po prawej stronie, przez sień idąc, jest pokój pierwszy, do którego drzwi malowane szparłowane na zawiasach, hakach żelaznych, $z$ zamkiem, $z$ kluczem, $z$ haczykiem i skoblikami ab intra do zakładania. Ten pokój obiciem warszawskim papierowem malowanym $^{\mathrm{d}}, \mathrm{z}$ lamperiami takiemiż $\left[{ }^{\mathrm{e}}\right]$, powała biała malowana, podłoga kwadratowa dobra, okien dwoje dobrych taflowych podwójnych, w ośmiu kwaterach otwierajacych się, na $^{\mathrm{f}}$ zawiaskach, haczykach, $z$ narożnicami, $z$ haczykami ze skoblikami i $z$ werblami żelaznemi. W tym pokoju jest kominek kapiasty, piec wielki biały dobry. Kafle w niebieskich leniach. Item w framugach jest szaf dwie wielkich $z$ półkami, zamykanych $z$ drzwiami podwójnemi, na zawiasach podwójnych, $z$ zamkami i z kluczami do zamykania.

Pokój drugi poboczny, do którego drzwi malowane szparowane zręcznością $z$ antabą $z$ zamkiem i $z$ kluczem dobrym, na zawiasach i hakach żelaznych. Ten pokój malowany i z powałą takąż. Podłoga taflowa dobra. Piec biały wielki kaflowy, w niebieskich paskach, dobry. Kominek szafiasty ${ }^{28} z$ cegły murowany. Okno jedno dobre $z$ krata żelazna, $z$ okiennica podwójna nowa, na zawiasach i hakach żelaznych, $z$ szworznikom ${ }^{29}$ i $z$ zatyczka żelaznemi. $Z$ tego pokoju sa drzwi nowe poboczne w murze wyłamane, $z$ futrynami futrowane, na zawiasach, hakach, $z$ zamkiem i $z$ kluczem nowemi, $z$ dwiema haczykami i czteryma skoblikami żelaznemi, w przyszłości do alkowego pokoiku. $Z$ tego alkowego sa drzwi tarciczne szparowane do prewetu na zawiasach i hakach, $z$ klamka, antaba, $z$ haczykami i skoblikami żelaznemi. W tym przyszłym alkowym posadzka $z$ cegły dobra, powała tarciczna zła.

Ten prewet $z$ drzewka starego $w$ słupy postawiony, gontami pobity dobremi. $Z$ tego preweta sa drzwi poboczne w odrzwiach nowych, na zawiasach, z klamką i zasuwa żelaznemi.

Item $z$ pokoju malowanego sa drzwi malowane szparowane do sieni, na zawiasach, hakach żelaznych, z zamkiem, z kluczem,

\footnotetext{
d Litera „m” nadpisana nad wierszem.

e Słowo nieczytelne.

f Nadpisane nad wierszem.

${ }^{28}$ Kominek szafiasty - mający kształt szafy, stawiany w szerokości ściany.

${ }^{29}$ Sworznik - zakończenie bieguna, na którym obraca się skrzydło drzwi.
} 
hantaba dobre[k. 34v]mi, w których jest haczyk z dwiema skoblikami w pokoju do zakładania.

Lamus i szufit w nim murowany, do którego drzwi żelazne $z$ zamkiem i z kluczem, $z$ dwiema wrzeciądzami, $z$ czteryma skoblami fundamentalnemi żelaznemi do zamykania opatrzony. Futryny i odrzwia drewniane. W tym lamusie jest okno w ramach nowych dobre, $z$ krata od cmentarza żelazna. Posadzka $z$ cegły poprawienia potrzebuje. Przy tym lamusie sa schody na górę budynkowa opaszone tarcicami, $z$ drzwiczkami, na zawiasach i hakach, $z$ wrzeciądzem i skoblami dwiema żelaznemi. Po prawej stronie, idac do lamusa, jest kominek $\mathrm{w}$ sieni szafiasty, murowany $z$ cegły. Item do pieców pokojowych $\mathrm{w}$ sieni sa tablatury ${ }^{30} \mathrm{z}$ drzwiczkami na zawiasach żelaznych podwójnych dane, aby się nie dymiło.

Idąc przez sień górna, na lewej ręce sa drwi tarciczne sz[p]arowane na zawiasach, hakach żelaznych, $z$ zamkiem dobrym bez klucza i $z$ antaba do kuchni. W tej kuchni jest okno dobre o dwóch kwaterach, na zawiasach i hakach żelaznych, z narożnicami i werblami żelaznemi. Kominek wielki szafiasty $z$ cegły murowany, $z$ powała i podłoga tarciczna. Przy tej kuchni jest pokoików dwa nowo reformowanych $z$ forsztów ${ }^{31}$, ściany heblowane i szparowane, do tych pokoików drzwi dwoje, do pierwszego nowe szparowane na zawiasach, hakach, $z$ zamkiem i kluczem nowemi, $z$ haczykim i skoblikami dwiema żelaznemi. Do drugiego pokoju sa drzwi składane $z$ zamkiem bez klucza, $z$ wrzeciądzem, o jednym skoblu. W tych pokoikach okien dwoje dobrych, kwatery na zawiasach i hakach, $z$ narożnicami żelaznemi i werblami takiemiż. Tragarze ${ }^{32}$ i powała dobra malowana, $z$ podłogami dobremi tarcicznemi. Kominek $z$ włoska nowo wymurowany $z$ cegły i piecem na chleb nowym $z$ cegły. Piec nowy obydwa pokoiki grzejacy, biały, kaflowy, $z$ niebieskiemi kwiatami, na fundamencie murowanym jeden.

Item $z$ pokoju do szpiżarni wielkiej są drzwi malowane na zawiasach i hakach, $z$ wrzeciądzem i skoblami żelaznemi. W tej szpiżarni jest okien dwoje, od spodu tylko do wpół okien szyby, a reszta gontami zaprawione. W tej szpiżarni dwie ściany murowane, a dwie $z$ drzewa $\left.n^{[g}\right]$ go zabudowane. Podłoga nowa $z$ forsztów, powała

g Uszkodzenie fragmentu tekstu na skutek niewłaściwego zszycia kart - „nowego"(?).

30 Tablatura - tafla, oprawiona płyta jako ozdobna zasłona.

${ }^{31}$ Forszty (foszty) - deski podłogowe.

${ }^{32}$ Tragarz - gruba belka stropowa biegnąca wzdłuż całej powały. 
$z$ dylów wylepienia potrzebuje. $Z$ tej szpiżarni do s[i]onki sa drzwi paradne na zawiasach, hakach, $z$ wrzeciądzem i skoblami żelaznemi. W tej s[i]once podłoga i powała tarciczna dobra. Item drugie drzwi do kuchni wyżej wspom[n]ionej górnej na zawiasach, hakach, $z$ wrzeciądzami żelaznemi. Trzecie drzwi $z$ tej sionki na cmentarz poboczne $z$ strony północnej na zawiasach, hakach, $z$ wrzeciądzem i skoblami żelaznemi. Nad temi drzwiami jest okno, szyby wybite, $z$ krata żelazna. $Z$ tej sionki sa schody do kuchni dolnej, nad temi schodami okno złe duże, szyby wytłuczone, $z$ kratą żelazna do kuchni, do której są drzwi na zawiasach, hakach, $z$ wrzeciązem i skoblami żelaznemi. Drugie item okienko niżej spuszczając się po schodach, bez szyb, $z$ kratka żelazną. Drugie drzwi z kuchni na podwórze, na zawiasach i hakach żelaznych, $z$ zamkiem, $z$ ryglem żelaznym, bez klucza. Ta kuchnia murowana, w której okno duże bez [k. 35] szyb, tylko krata żelazna.

Piwnica w dolnej sieni pod schodami jak kontraktem, tak i inwentarzem ekscypuje się $z$ wódkami remanentowemi jak teraz, tak i na potym J.W. chełmskiego deputata i proboszcza mał[o]go[skiego] ${ }^{33}$.

\section{$\underline{\text { Sad }}$}

Naprzeciwko probocztwa $z$ strony południowej z różnemi drzewami [ ${ }^{\mathrm{h}}$, sad ten rozmnożenia potrzebuje, w tym sadzie jest kwater trzy na różne włoszczyzny, ad p[rae]sens ${ }^{34}$ wszystkie trzy obsiane różnemi nasionami i przed św. Janem Chrzcicielem [24 VI] oplewione. Item i chmiel jest w tym sadzie zupełnie załyczony.

Ten zaś sad miejscem parkanami obwiedziony, miejscem od pola płotami ogrodzony. Do którego jest brama dobra ze wszystkim $^{\mathrm{i}} \mathrm{w}$ słupach wyrobionych, $\mathrm{z}$ podwójnemi wrotniami ${ }^{35} \mathrm{w}$ sztachety robionemi, bratnalami ${ }^{36}$ przybijane i $z$ furtką takaż, na kunach i czopach, jak wrotnie, tak i furtka żelaznych osadzone, $z$ haczykiem i skoblikami żelaznemi, $z$ wrzeciądzem i $z$ skoblami takiemiż tak $z$ sadu, jako i $z$ podwórca.

\footnotetext{
h Dwa wyrazy nieczytelne (rozmazany atrament).

${ }^{i}$ Litera „w" nadpisana nad wierszem.

${ }_{33}$ Mowa o ks. Ignacym Józefie Malczewskim.

${ }^{34}$ Ad praesens (łac.) - obecnie.

${ }^{35}$ Wrotnia (wrótnia) - wrota.

${ }^{36}$ Bratnal (bretnal) - gwóźdź o płaskim i dużym łebku.
} 


\section{$\underline{\text { Folwark }}$}

Dawny $z$ drzewa sosnowego na kostkę obrabianego $w^{[j]}$ na przyciesiach postawiony gontami. Komin $z$ glina wałkami pleciony, na wierzch wywiedziony, gontami obity. Mostek przed folwarkiem $z$ dylów dany dobry. Wchodząc do sieni, są drzwi tarciczne na zawiasach, hakach, $z$ wrzeciądzem i $z$ skoblami żelaznemi, z klamka drewniana. Idacc przez sień, na lewej ręce sa drzwi do izdebki tarciczne na zawiasach, hakach, $z$ wrzeciądzem i skoblami żelaznemi oraz $z$ haczykiem i skoblikami $z$ izby do zakładania. W tej izbie piec kaflowy zielony, kominek kapiasty, lawek przy piecu dwie, powała dobra, podłoga reparacji potrzebuje. Okna w ramach dwa dobre, jedna szyba wybita. $Z$ izdebki sa drzwi tarciczne do komory na zawiasach, hakach, $z$ wrzeciądzami, skoblami żelaznemi. W tej komorze okno małe, w którym dwóch szyb nie masz, $z$ powała bez podłogi, szafa o dwóch półkach jedna. Przez sień do piekarni sa drzwi tarciczne na zawiasach, hakach, $z$ wrzeciądzem i skoblami żelaznemi. W tej piekarni jest piec murowany z kamienia i piec drugi chlebowy $z$ kominkiem kapiastem. Okno szyby w drewno oprawne, w tym oknie brakuje siedmiu szyb. Izba i komora $z$ powała dobra bez podłogi, sień $z$ powała bez podłogi. $Z$ komory na podwórzec sa drzwi na zawiasach o jednym haku, $z$ kołowrotkiem drewnianym. Od tego folwarku ciagnie się parkan dobry $z$ płatwami ${ }^{37}$ aż do browaru. Na tym folwarku $z$ strony południowej dach reparacji potrzebowal, ad p[rae]sens jest zreparowany dobry.

\section{$\underline{\text { Statki folwarczne }}$}

Stę[k. 35v]pa ${ }^{38}$ jedna, żłób dla krów i żłóbek dla cieląt drugi, dzieża ${ }^{39}$ chlebowa jedna, skopiec ${ }^{40}$ jeden, siekacz jeden, niecki kapustne jedne, sznury do wycierania sadzy dobre.

j Słowo nieczytelne (wyblakłe pismo).

${ }^{37}$ Płatew - pozioma belka prostopadła do więzarów, podpierająca krokwie.

${ }^{38}$ Stępa (moździerz kaszarski) - urządzenie do obłuskiwania i kruszenia ziarna na kaszę.

${ }^{39}$ Dzieża - naczynie do rozczyniania i mieszania makki na chleb.

40 Skopiec - naczynie z klepek o pojemności do 5 litrów (wiadro), przeznaczone do udoju krów. 


\section{Wołownia}

Z dylów w słupy postawiona, snopkami poszyta, w szczycie od gumna sa $\left.{ }^{[\mathrm{k}}\right] \mathrm{z}$ deszczek składane na biegunach drewnianych, $z$ wrzeciądzem i skoblami żelaznemi, bez powały i podłogi, $z$ dwiema przegrodami dla wołów ${ }^{1}$ roboczych i dla [ $\left.{ }^{\mathrm{m}}\right]$. W tej wołowni jest żłobów dobrych trzy, drabin dwie. Między wołownia a folwarkiem jest parkanek i $\left.{ }^{\mathrm{n}}\right]$ reparacji potrzebujace.

\section{Stodoły}

Pierwsza stodoła $z$ frontu nowo postawiona na wschód słońca, $z$ drzewa sosnowego kostkowego, pod topór obrabianego, o dwóch zapolach ${ }^{41}$ wielkich, snopkami poszyta, od spodu dwiema szarami gontowemi pobita, $z$ wrotami tarcicznemi składanemi, na czopach i kunach żelaznych, $z$ wrzeciądzami i skoblami żelaznemi i z zawłokami takiemiż do zamykania jak $z$ frontu, tak i $z$ gumna stodół.

Druga stodoła wielka o dwóch bojowiskach ${ }^{42}$, o trzech zapolach na zachód słońca dawna, $z$ drzewa sosnowego pod topór na kostkę obrabianego, w węgły postawiona, snopkami poszyta, a od spodu dwiema szarami gontów pobita, $z$ wrotami tarcicznemi dobremi, na biegunach drewnianych $z$ kunami, $z$ wrzeciądzami, skoblami i zawłokami żelaznemi od pola do zamykania. Te stodoły dwiema kawami ${ }^{43} \mathrm{w}$ kwadrat sa zabudowane, $z$ strony północnej ściany od pola sa dane w słupach $z$ wozownia, do której sa wrota tarciczne dawne składane na biegunach drewnianych, $z$ wrzeciądzem i skoblami żelaznemi. Przy tej wozowni jest komora nowo postawiona na obroki, plewy, zgarniny, do której drzwi tarciczne na zawiasach, hakach, $z$ wrzeciądzem i skoblami żelaznemi, $z$ podłoga, bez powały pod snopkami. Item kawa druga duża na słomy $z$ dylów w słupy postawiona, snopkami poszyta, $z$ strony południowej od pola

k Słowo nieczytelne - „wrota”(?).

${ }^{1}$ Litera „w" nadpisana nad wierszem.

m Wyraz nieczytelny.

n Słowo nieczytelne (rozmazany atrament).

${ }^{41}$ Zapole - część stodoły przeznaczona do składowania zboża.

42 Bojowisko - znajdujacce się między dwoma zapolami klepisko, służące m.in. do młócenia zboża.

${ }^{43}$ Kawa - daszek na słupach, wystawka do składania drewna, także szopa. 
strzałami ściany utwierdzone, oraz i z gumna jest strzała dana. $\mathrm{Na}$ tych budynkach częścią kalenice gontami pobite, a częścią z słomy poukładane dobre pod koziołkami.

\section{Szpichlerz}

W środku gumna $z$ drzewa sosnowego, w kostkę pod topór obrabianego, dawno postawiony w węgły, pod snopkami z kalenica, od spodu gontem pobity. Do którego sa drzwi tarciczne na zawiasach, hakach, $z$ wrzeciądzem, skoblami żelaznemi, z zamkiem i z kluczem takiemiż.

$\mathrm{W}$ tym szpichlerzu jest fas ${ }^{44}$ dwie $z$ wiekami ćwierć miary [ $\left.{ }^{\circ}\right]$ jedna, strych jeden, miarka dwugarncowa jedna, szufel dwie, młynek do [k. 36] chędożenia zboża $z$ korbami żelaznemi dobry jeden.

Idąc od stodół, jest parkan po lewej ręce do wrót od pola dany [?]. Ten parkan potrzebuje przystawienia i nakrycia płatwami nowemi. Przy tym parkanie jest furtka zabudowana, przy niej wrota składane na biegunach drewnianych, $z$ wrzeciądzem i skoblami żelaznemi, zawierające się od pola. Od tych wrót ciągnie się płot przez górę aż do chałupy chłopskiej, w której mieszka Stefan zagrodnik, przeszły gorzalany.

\section{$\underline{\text { Szpichlerz }}$}

Drugi w dzie[dzi]ńcu pod góra, ex oppo[sito] ${ }^{45}$ do folwarku, na przyciesach $\mathrm{w}$ koło podmurowanych, $z$ drzewa sosnowego pod topór obrabianego, dawny, w węgły postawiony, $z$ karpa nowa murowana na wapnie stwardzony, pod górę gontami pobity, do którego $z$ podwórca sa schody nowe. Drzwi tarciczne na zawiasach, hakach, $z$ wrzeciądzem i skoblami żelaznemi, $z$ zasuwa drewnianą, do której klucz żelazny, $z$ podłoga tarciczna, powała $z$ dylów. Schody na górę $z$ drzwiami, $z$ wrzeciądzem i skoblami żelaznemi. W tym szpichlerzu jest sąsieków ${ }^{46}$ cztery na zboże $z$ przegrodami $z$ forsztów sosnowych dane.

\footnotetext{
- Słowo nieczytelne.

${ }^{44}$ Fasa - naczynie drewniane, stagiew, beczka.

${ }^{45}$ Ex opposito (łac.) - naprzeciwko, na wprost.

${ }^{46}$ Sąsiek - tu: skrzynia, paka na zboże.
} 


\section{$\underline{\text { Karczma }}$}

Podkościelna dawna $z$ drzewa sosnowego w kostkę obrabianego, $\mathrm{w}$ węgły postawiona, $z$ sienia, $z$ izba i $z$ komora pod jedna strzecha, [p]tami pobita. Wchodząc do sieni, sa wrota pojedyncze na czopach i kunach żelaznych. W tej sieni kumin wielki w stagach drewnianych w belkach osadzone, wałkami słomianemi $z$ glina pleciony i wytrynkowany na wierzchu, cegła nadmurowany. $Z$ sieni w prawa rękę sa drzwi do izby tarciczne na zawiasach, hakach, $z$ wrzeciądzem i skoblami żelaznemi, ['] z piecem chlebowym $z$ cegły murowany, kominek kapiasty murowany. Stołów dwa, większy i mniejszy, ław trzy przy stołach, przy piecu ławek dwie, szafa na statki szynkarskie jedna. Okna dwa dobre $z$ okiennicami, szyby w drewno oprawne.

W tej karczmie jest piwnica murowana, do niej drzwi z izby składane na zawiasach, hakach, $z$ wrzeciądzem i skoblami żelaznemi. $Z$ izby do komory sa drzwi tarciczne dobre na zawiasach, hakach, $z$ wrzeciądzem i skoblami żelaznemi. Ta komora $z$ powała tarciczna, bez podłogi. W izbie podłoga i powała dobra.

\section{Naczynia w karczmie}

Podkościelnej, baryłka na ordynary[j]ną wódkę dębowa, w której gar. $\underline{8} \mathrm{k}[$ war]ta jedna, druga baryłka na wódkę przepalana półpiątogarncowa ${ }^{47}$ jedna, półgarncówek ${ }^{48}$ drewnianych $\underline{3}$, czwarta blaszana jedna, drewniana jedna, półczwarcie blaszane jedno, kwate$\operatorname{rek}^{49}$ blaszanych $\underline{3}$, półkwarcie ${ }^{50}$ blaszane jedno, lejek blaszany $\underline{1}$.

\section{$\underline{\text { Karczma }}$}

Nowo postawiona wie[k. 36v]zna [s] zwana pod Pierzchnica ${ }^{51}$ na Gościńcu Częstochowskiem, na przyciesiach sosnowych, z drzewa kostkowego sosnowego pod topór obrabianego, $z$ stajnią wiezną

p Kilka liter nieczytelnych - „gontami” (?).

${ }^{r}$ Wyraz nieczytelny.

s Wyraz nieczytelny.

47 O pojemności cztery i pół garnca (1 garniec $=3,76$ litra).

48 Naczynie o pojemności pół garnca.

49 Naczynie (zwykle blaszane) o pojemności około 1 litra.

50 Naczynie o pojemności równej połowie kwarty (1 kwarta $=0,9422$ litra).

${ }^{51}$ Pierzchnica - miasto w dawnym powiecie chęcińskim, około $40 \mathrm{~km}$ na południowy zachód od Małogoszcza. 
$z$ drzewa rzniętego pod sznur szparcowanego w ściany. Wierzch $z$ wiązaniami należytemi, $z$ wrotami okładanemi tarcicznemi, na biegunach drewnianych, $z$ wrzeciądzem i skoblami żelaznemi. Item wrota drugie $\mathrm{w}$ okapie $\mathrm{w}$ tęcza danym, na biegunach drewnianych, $z$ furtka tarciczna, $z$ wrzeciądzami i skoblami jak u wrót, tak i u furtki żelaznemi.

W tej karczmie sa dwie izby $z$ dwiema komorami. Drzwi tarciczne stolarska robota pięcioro, na zawiasach, hakach żelaznych i dwojga drzwi, wrzeciądze i skoble żelazne. Okien troje taflowych, szyby w drewno oprawne $z$ okiennicami dwiema, na zawiasach, hakach i z szworznikami, zatyczkami żelaznemi, o jednym kominie wielkim, wałkami $z$ glina plecione i wytrynkowany, $z$ którego wierzch cały cegła nadmurowany i w tych dwóch izbach jest kominków dwa, partem $z$ cegły, partem $z$ kamienia murowane. Powały tarciczne jak w izbach, taki i w komorach bez podłogów. W izbie szynkowej jest stół i zedel stolarska robota dobry, z Popowic dany. Ta karczma jest postawiona frontem na południe, $z$ wystawa i $z$ sztybrami $^{52}$ drewnianemi. Pod wystawa jest pięć słupów wyrobionych ${ }^{t}$. Stajnia $z$ żłobami, $z$ drabinami, bez powały i podłogi. Ten budynek i z stajnia wraz jest gontem pobity. Przy tej karczmie zaraz za stajnią na wschód [?] słońca jest studnia nowo wybita i w wodę obfita, drzewem rzniętem wycembrowana, $z$ walcem, $z$ wiadrem i $z$ lina konopna do wyciagania wody. Item drabina nowa jest w tej karczmie na górę.

\section{Inwentarz osiadłości poddanych}

Jakub zagrodnik pieszych dni - - 3

Paweł zagrodnik - - dni - - 3

Stefan zagrodnik - - dni - - 3

Witek zagrodnik - - dni - - 3

Antek zagrodnik - - dni - - 3

Stach Tracz - - - - dni - - 2

Powinności tycze takowe, sadze w tydzień w kole wycierać we wszystkiech na probocztwie kominach i kominkach na folwarku

\footnotetext{
t W podstawie wydania: „wyrabionych”.

52 Sztyber - słup, belka nośna.
} 
i w browarze gorzelany, pilność mieć powinien o sadzach. Trzodę chlewna od św. Wojciecha [23 IV] do św. Marcina [11 XI] w kolej pasać powinni bez szkody, rosadę wybrać i tę należy mu się zasadzić. Dziesięciny jak młynarz, tak i zagrodnicy nie dają. Ad p[rae]sens Wojciech Łataś, młynarz przychodni siedzi na młynie za kontraktem, do którego ma i inwentarz opisany. Daje czynszu z młyna i z gruntu rocznego złp $\underline{100}$ i kapłonów № $\underline{2}$ wraz z czynszem oddać powinien. Co się tycze podymnego $z$ młyna, to jest przyłączone do czynszu. Ten za czynsz wypłaca dwiema ratkami na św. Marcin № $\underline{3}$, na św. Jana Chrzciciela $\underline{3}$ i mleć tak do szpiżarni, jako do browaru co tylko potrzeba powinien bez miarek.

Podymnego na dwie raty, septembrowa i marcowa, należy się na rok złp $\underline{6}$. $Z$ kuminów wszystkich, tak $z$ dworskich, jako i $z$ gromadzkich, to podymne od[k. 37]daje się do miasta, a P[ano]wie Burmistrze $z$ odebranego tego podatku obligowani $z$ każdą ratką kwity dawać.

Notandum od zagrodnika trzydniowego należy się na ratkę złp 2 gr 15, od chałupników i komorników po złp $\underline{2}$. Item oprawy po łokci sześć wszyscy zagrodnicy $z$ przędziwa dworskiego odważonego oprząść, uprać, na kłębki duże i do dworu oddać powinni tę przędzę. Item i czas poddani odrobiwszy powinne dni, iść powinni na zarobek za pieniądze do jakowej [u] roboty rozkaże, a płaca im takowa należy podług dawnych inwentarzów od kosy za dzień gr $\underline{20}$, kiedy pójda $z$ kosami do Popowic. Ponieważ łąką Wielka zwana jest przyłączona kontraktem W. Dzierżawcy probocztwa małogoskiego, zaś od siekiery, młocki za dzień po gr $\underline{15}$, od żniwa pszenicznego po gr 16 podczas żniw, od żyta i jarzyn po gr $\underline{15}$, od plewidła i sianograbienia po groszy sześć za dzień gruntowym ludziom.

Ostrzega się niniejszym inwentarzem, aby poddani nic nad inwentarz nie byli obciążeni, ponieważ to ludzie sa wszyscy ${ }^{\mathrm{w}}$ przychodni.

Także parobcy dworscy, którzy mają swoje mieszkania i z żenami, więc powinni odrabiać dzień w tydzień komorny od św. Wojciecha do św. Marcina, i podymnego na rok wytrąca im się z zaszłej złp cztery.

Gajowy Stach Kosior osadzony na trzydniowej zagrodzie pod Pierzchnica w karczmie nowej, aby lasu pilnował wiernie i szczerze. Któremu to gajowemu pańskim ziarnem i bydłem zaorano,

\footnotetext{
u Wyraz nieczytelny.

w Litera „w" nadpisana nad wierszem.
} 
zaprawiono i obsiano tak na zimę, jako i teraz na wiosnę żyta korzec $^{53}$ jeden, jęczmienia korzec ćwierć jedna, tatarki ćwierci trzy. Ma do tej zagrody przydaną łączkę i ogród. Item jest mu dany instruktarz $z$ opisaniem jego powinności i do tego powinien podymnego płacić wraz $z$ inszemi zagrodnikami na rok złp [y], od dziesięciny jest wolny.

\section{Ogrody dworskie}

Jest ogród nowo erygowany pod Babink[i]em ${ }^{54}$ żerdzami w słupach garowanych, w kołach dębowych ogrodzony, w którym znajduje się jarzyny ogrodowy, to jest pasternaku zimowego zagonów $\underline{4}$, marchwie zagonów № $\underline{9}$, buraków zagonów dwa, maku zagon $\underline{1}$, ziemniaków zagonów $\underline{3}$, grochu białego piechoty ${ }^{55}$ zagonów $\underline{2}$, konopi zagonów $\underline{7}$.

Drugi ogród pod Sabianowem ${ }^{56}$ w koło płotami chruścianemi obwiedzony, $z$ przytażem $z$ dylów w słupkach danymi, toż samo i pod Babink[i]em jest przytaż $z$ dylów w słupach dany. W tym ogrodzie jest kapusty zasadzonej zagonów $\underline{30}$ i karpieli ${ }^{57}$ półtora zagona.

Te obydwa ogrody należycie obsiane, kapusta zasadzone, oplewione przed św. Janie według czasu, więc i W.J.Pan Dzierżawca przy operacji $\mathrm{w}$ jakowym stanie odbiera, w takowym obligowany oddać.

\section{Statki gospodarskie}

Wozów kowanych dobrych $z$ wszystkiemi ${ }^{z}$ potrzebami, $z$ blachami, stosami, $z$ lonami ${ }^{58}, z$ zatylnikami ${ }^{59}, z$ worazkami [?], z sworzniami, $z$ dyslami okutemi, $z$ wagami okutemi żelazem, jeden koński,

y Cyfra nieczytelna (wyblakłe pismo).

${ }^{z}$ Litera "w" nadpisana nad wierszem.

531 korzec $=32$ garnce $=120,6$ litra.

${ }^{54}$ Babinek - wzgórze położone około 800 m na zachód od rynku w Małogoszczu. Obecnie znajduje się tam rozległy cmentarz parafialny.

${ }_{55}$ Piechota - fasa karłowata nieidaca na tyczki, nazywana też grochem.

${ }^{56}$ Sabianów - dawniej nazwa zalesionego wzgórza, obecnie jedna z ulic w Małogoszczu.

57 Karpiel - rodzaj brukwi.

58 Lon (poter) - drewniana zatyczka osi wozu, zabezpieczająca koło przed spadnięciem.

${ }^{59}$ Zatylnik - deska zamykajacca $z$ tyłu wóz. 
drugi wołowy № 2. Do tych wozów spodniarek ${ }^{60} \underline{2}$, drabin kopnych $z$ luśniami ${ }^{61}, z$ czopami żelaznemi par $\underline{2}$, kołowrotów do tych drabin $\underline{2}$, gnojnic $z$ obartlami ${ }^{62}$ dwie pary.

Pługów dwa dobrych $z$ żelazami płużnemi, $z$ kołkami refowanemi i budowanemi, styków [?] okutych $\underline{8}$, kurków żelaznych $\underline{2}$, wici do płu[k. 37v]gów żelaznych dwie, radeł $z$ radlicami okuwanemi $\underline{4}$, bron $z$ gwoździami żelaznemi dobrych para jedna, jarzm ${ }^{\dot{z}}$ $z$ wiciami drewnianemi cztery, kosa $z$ skrzynką i stalicą ${ }^{63}$ do sieczki jedna dobra, sierpów dobrych $\underline{3}$, sani nowych fornalskich $z$ pieskami $\underline{2}$, sanki bronne nowe $\underline{1}$, kłódek $z$ kluczami dobrych $\underline{4}$, siekier dobrych $\underline{2}$, kłoda ${ }^{64}$ na kapustę dębowa $z$ pokrowa $[s]$ i $z$ kamieniami do przyciśnienia $\underline{1}$.

\section{Zaprzèż fornalska}

$\left.{ }^{[\dot{z}}\right] \mathrm{z}$ postronkami para $\underline{1}$, lecarek konny $\underline{1}$, opałka na $z g o n i n y^{65}$ dobra $\underline{1}$, nosze jedne, dragi pod piwo jedne.

\section{$\underline{\text { Koni fornalskich }}$}

Podjezdek gniady i klacz myszata, $z$ pracej skorej [s] ma zacięgi na oczach, letnie oboje, para jedna. ${ }^{\text {aa }}$

\section{Woły robocze}

Wół sady ${ }^{66}$ dawny $z$ dużemi rogami, 2gi gniady [ $\left.{ }^{\mathrm{ab}}\right]$.

Item wołów kupiono w Roku Pańskim 1786 na kwietni jarmark w Kielcach $\underline{1}$, sady sami przez się $\underline{2}$, płowy pod brzuchem biały $\underline{3}$,

${ }^{2}$ Litera „m” nadpisana nad wierszem.

¿̇ Słowo nieczytelne.

aa Dopisane inną rękę: „Te się odebrały do Popowic ks. mało[goski]”.

ab Słowo nieczytelne (wyblakłe pismo).

60 Spodniarka - spodnia deska, dno wozu.

${ }^{61}$ Luśnia - element wozu drabinowego, drewniana podpora - jednym końcem w oś zatknięta, drugim podpierajaca drabinę do zboża lub siana.

${ }^{62}$ Obartel - ruchomy element (kołowrót) na przedniej osi wozu, umożliwiający skręcanie.

${ }^{63}$ Stalica - żelazne okucie skrzynki w sieczkarni ręcznej.

${ }^{64}$ Kłoda - duża beczka.

${ }^{65}$ Zgoniny - kawałki słomy pocięte w czasie młocki i wyrzucone na zewnątrz młocarni lub oddzielone od ziarna przy wianiu zboża.

${ }^{66}$ Sady (szady) - szary, siwy, popielaty. 
czerwony sam bez się $\underline{4}$, bury bez odmiany, rogi ma pochyłe. Te cztery woły kosztuja złp $\underline{267}$, na tych wołach jest powrozów konopnych $\underline{6}$.

\section{Wysiew zboża ozimego i jarego na gruntach proboszczow[skich] 1786}

Żyta wysiano korcy 20 -"- zagonów № - - 1500

Pszenicy -"- kor. 12 ćwierć 3 miar 2 zagonów № - - 320

Jęczmienia -" - kor. 13 -"- 1 -"— zagonów № - - 552

Grochu -"- kor. 1 -"- 2 -"— zagonów № -" - 94

Owsa -"- kor. 22 -" - 2 - - zagonów № - - - 580

Siemienia konopnego - - - kor. 1 zagonów № —"— ac

Tatarki —"- kor. 2 zagonów № —"- 95

Zagonów $\underline{36}$ wysiano - - ćwierć 1, gar. 1, który przed św. Janem oplewiony.

Chałupa przeciwko kościoła na górce $z$ drzewa sosnowego w węgły postawiona, dranicami pobita do inwentarza nie powinna należyć, tylko dla służących kościelnych ostrzega się. ${ }^{\text {ad }}$

Przyłącza się do tego inwentarza ordynaria dla P[a]na Dyspozytora oraz i dla czeladzi folwarcznej, zostawiona na gruncie kwartalna od św. Jana do św. Michała, to jest pszenicy przedni kor. 1 ćw. $\underline{1}$ gar. $\underline{2}$, odzimnej [?] pszenicy ćw. $\underline{3}$ gar. $\underline{6}$, żyta kor. $\underline{7}$, jęczmienia kor. $\underline{6}$, grochu kor. 1 ćw. $\underline{1}$ gar. $\underline{4}$, tatarki kor. $\underline{1}$ ćw. 1 gar. $\underline{4}$. Tę zaś ordynaria kwartalna zostawiona dla szerega czeladzi podczas eksploracji [?] kontraktu obligowany W.J.Pan Posesor dzierżawny tak czeladź, jako i zboże na tęż czeladź zostawić do św. Michała i dla P. Dyspozytora oddać in natura ${ }^{67} z$ bożem ${ }^{a e}$.

$\mathrm{W}$ sieni górnej jest kredens wielki w orzech malowany dobry, z zamkami i kluczami dobremi 3ma. Waz trzy na wierzchu wyzłacanych.

ac Brak wartości.

ad Dopisek inną ręka: "Niniejszym inwentarzem”.

ae „m” nadpisane nad wierszem. Dalej fragment tekstu dopisany inną ręka (nieczytelny).

67 In natura (łac.) - w naturze (nie pieniędzmi). 


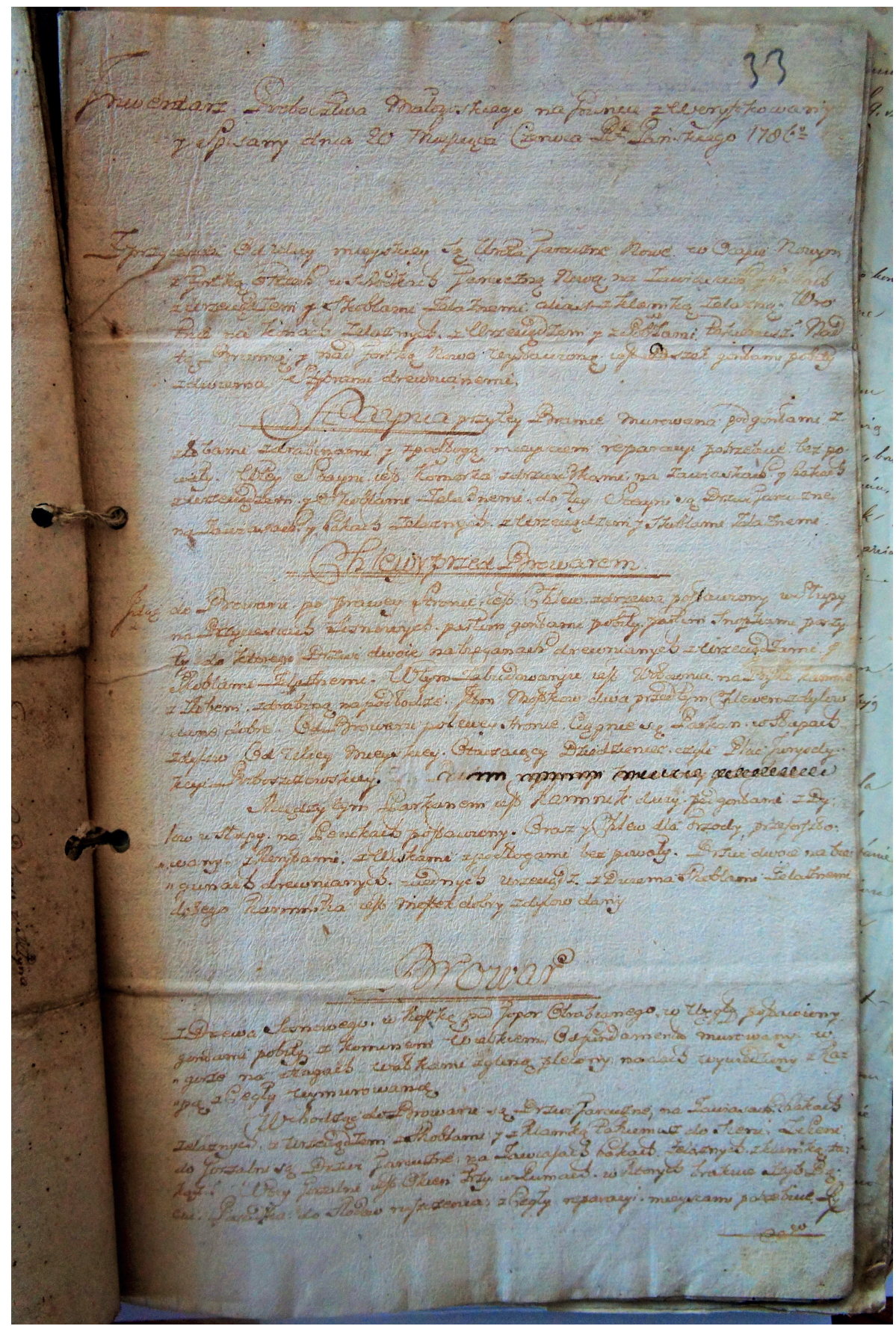

Karta tytułowa inwentarza probostwa w Małogoszczu z 1786 r.

Fot. M. Karkocha, 2019 
Przed św. Janem Chrzcicielem ugory pszeniczne wszystkie ${ }^{\text {af }}$ pod Babink[i]em spokładane ${ }^{68}$, oraz i pod Sabianowem żytnych ugorów zagonów skibnych $\underline{360}$ jest położonych. Oddaja się tym inwentarzem. [k. 38]

W pokoju pierwszym portrytów jest pięć, w drugim pokoju jest obraz św. Michała.

ag-Ten inwentarz $\mathrm{w}$ roku przeszłym opisany probostwa na przyszłą trzechletnia posesję przyjmuję oprócz wołu, który się zepsuł, a tych nie zostaję na inwentarz tylko № 5, sivo [?] pięć, z tego zaś zepsutego wołu otaksowana skóra i mięso złp osiemnaście, obliguję się za te złp 10 kupić ciołeczka ${ }^{69} \mathrm{w}$ pierwszym roku.

$\mathrm{D}$ [nia] 6 maja $1787^{\text {-ag }}$

Ks. Malczewski, pr[oboszcz] małog[oski] Kajetan Zakrzewski m.pp. [pieczęć]

[pieczęć]

\section{Bibliografia}

\section{Ź Ródea ARCHIWALNE}

Archiwum Diecezjalne w Kielcach

Małogoszcz. Akta dokumentów kościoła parafialnego w Małogoszczu od 1709 r., sygn. IIPM-I/2.

Małogoszcz. Dokumenty różne z XIX wieku (luzem, nieuporządkowane), sygn. IIPM-I/6.

\section{Ź RÓDEA DRUKOWANE}

Corpus inscriptionu Poliniae, t. I (Województwo kieleckie), red. J. Szymański, z. 2 (Jędrzejów i region jędrzejowski), wydała, wstępem i komentarzem opatrzyła B. Trelińska, Kielce 1978.

\section{Opracowania}

Achremczyk S., Marchwiński R., Przeracki J., Poczet biskupów warmińskich, Olsztyn 1994.

Dominikiewicz M., Wyrób piwa, wyd. 2 na nowo oprac. i powiększone, Łódź-Katowice 1923.

\footnotetext{
af Litera „w" nadpisana nad wierszem.

ag-ag Dopisek inną ręką.

68 Spokładane - zorane płytko.

${ }^{69}$ Ciołeczek - cielak, cielę.
} 
Hadamik C., Kalina D., Traczyński E., Miasto i gmina Małogoszcz, Kielce 2006 (seria: Dzieje i zabytki małych ojczyzn, red. R. Mirowski).

Instrukcja wydawnicza dla źródeł historycznych od XVI do połowy XIX wieku, red. K. Lepszy, Wrocław 1953.

Janicka-Szyszko R., Słownictwo rzemiosł w drewnie w leksyku doby nowopolskiej, [niepubl. rozprawa doktorska], Gorzów Wielkopolski 2019.

Jastrzębski C., Bitwa pod Małogoszczem 1863, Małogoszcz 2013.

Karkocha M., Epigrafika w Małogoszczu XVI-XVIII w., „Acta Universitatis Lodziensis. Folia Historica" 2015, nr 95, s. 21-49.

Karkocha M., Opis probostwa w Małogoszczu z 1856 roku, „Przegląd Nauk Historycznych" 2018, R. XVII, nr 1, s. 143-170. https://doi.org/10.18778/1644-857X.17.01.07

Karkocha M., Opis wizyty dziekańskiej kościoła parafialnego w Małogoszczu z roku 1830, „Przeglad Nauk Historycznych” 2016, R. XV, nr 2, s. 261-283. https: / / doi.org/ 10.18778/1644-857X.15.02.09

Karkocha M., Prebenda św. Anny w Małogoszczu $w$ połowie XIX stulecia, „Przegląd Nauk Historycznych” 2018, R. XVII, nr 2, s. 269-284. https://doi.org/ 10.18778/1644-857X.17.02.11

Karkocha M., St. Anne's prebend in Małogoszcz in the mid-nineteenth century, „Przegląd Nauk Historycznych” 2018, R. XVII, nr 3, s. 271-286. https://doi. org/10.18778/1644-857X.17.03.11

Karkocha M., Uposażenie parafii Małogoszcz $w$ świetle sumariusza z 1792 r., „Przegląd Nauk Historycznych” 2016, R. XV, nr 1, s. 249-276.

Karkocha M., Wystrój i wyposażenie kościoła parafialnego w Małogoszczu w świetle inwentarza z 1856 roku, „Przegląd Nauk Historycznych” 2017, R. XVI, nr 1, s. 325-362. https://doi.org/10.18778/1644-857X.16.01.10

Katalog zabytków sztuki w Polsce, t. III (Województwo kieleckie), red. J.Z. Łoziński, B. Wolff, z. 3 (Powiat jedrzejowski), oprac. T. Przypkowski, Warszawa 1957.

Kosik E., Chrostowice z Małogoszcza, „Nasza Przeszłość” 1973, R. XL, s. 175-182.

Kosik E., Parafia małogoska, [w:] W kasztelańskim Małogoszczu. Monografia historyczno-gospodarcza Małogoszcza i okolicy, red. E. Kosik, Kielce 1994, s. 59-66.

Kosik E., Paulewicz M., Budowniczy Małogoszcza Jakub Bieda Chrostkowicz, [w:] W kasztelańskim Małogoszczu. Monografia historyczno-gospodarcza Małogoszcza i okolicy, red. E. Kosik, Kielce 1994, s. 67-70.

Kumor B., Dzieje diecezji krakowskiej do roku 1795, t. I, Kraków 1998.

Łacny K., Janczar-Smuga M., Postęp techniczny i technologiczny $w$ produkcji sło$d u$, „Nauki Inżynierskie i Technologiczne” 2013, nr 4(11), s. 77-93.

Łętowski L., Katalog biskupów, prałatów i kanoników krakowskich, t. II (Biskupi krakowscy), Kraków 1852.

Nitecki P., Biskupi Kościoła w Polsce w latach 965-1999, Warszawa 2000.

Rawita-Witanowski M., Dawny powiat chęcinski, z ilustracjami prof. J. Olszewskiego, oprac. D. Kalina, Kielce 2001.

Wiśniewski J., Historyczny opis kościołów, miast, zabytków i pamiątek $w$ Jędrzejowskiem, Marjówka 1930 (reprint: Kielce 2000). 
NotKa O AUTORCE:

Dr Malgorzata Karkocha - adiunkt w Katedrze Historii Nowożytnej, w Instytucie Historii Uniwersytetu Łódzkiego.

Zainteresowania naukowe: historia nowożytna powszechna XVI-XVIII w., dzieje kultury i sztuki XVI-XVIII w., Francja w dobie Wielkiej Rewolucji (1789-1799), prasa okresu stanisławowskiego, epigrafika, kampanologia.

(길.lgorzata.karkocha@uni.lodz.pl 